\title{
Entrepreneurial ecosystems created by woman entrepreneurs in Botswana
}

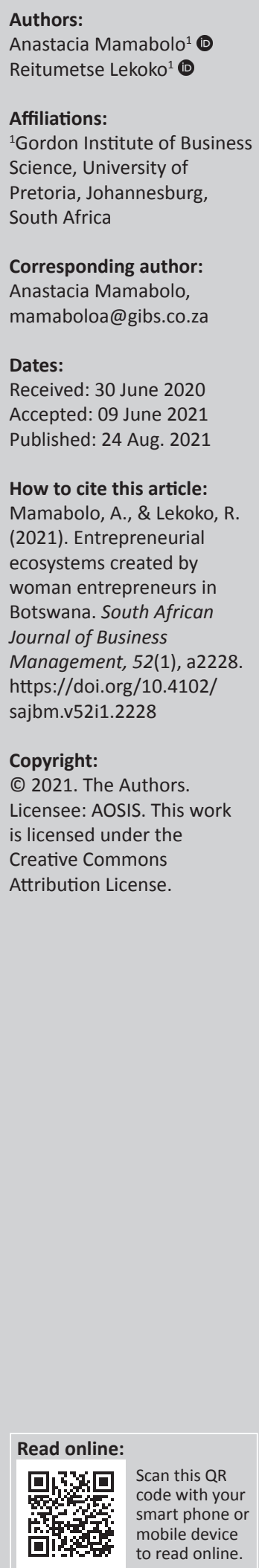

Purpose: The aim of this study was to explore how woman entrepreneurs in a developing country context such as Botswana create their own entrepreneurial ecosystems that support their business-venturing activities.

Design/methodology/approach: This qualitative research collected data via in-depth interviews from a purposive sample of 11 women who owned established enterprises in Gaborone, Botswana.

Findings/results: Firstly, woman entrepreneurs in Botswana displayed entrepreneurial behaviours, skills and characteristics, an ability to overcome marginalisation and a positive attitude towards failure. Secondly, the entrepreneurial ecosystems created by women included social capital ties, human capital development, alternative funding mechanisms, access to local and international markets and inclusion of digital technology as part of the ecosystem. The woman entrepreneurs were influenced by the entrepreneurial institutional conditions in Botswana. Lastly, the findings showed the significance of changes to each component of the entrepreneurial ecosystem across the stages of the entrepreneurial journey.

Practical implications: In a context of limited entrepreneurial resources, woman entrepreneurs should build their own ecosystem by leveraging the existing social networks and collaborating with local and international stakeholders. Government should design tailor-made entrepreneurial programmes and foster public and private partnerships to support the advancement of woman entrepreneurs. Lastly, ecosystem players including private institutions should collaborate to support women-owned entrepreneurial ventures.

Originality/value: This study adopted an alternative view that woman entrepreneurs can be the key drivers of the entrepreneurial ecosystem. This system must be built up from the level of the women entrepreneurs to better understand their specific stance and also the context in which they operate.

Keywords: emerging market; entrepreneurial ecosystem; women entrepreneurship; institutional theory; entrepreneurial behaviours.

\section{Introduction}

The prevalence of entrepreneurship is increasing amongst women in sub-Saharan Africa and is contributing to innovation and the creation of jobs, thereby improving the livelihood of families and communities (Adom \& Asare-Yeboa, 2016; Lock \& Smith, 2015). Despite its significance, research in sub-Saharan African regions shows that, in most countries, the entrepreneurial activities of woman entrepreneurs are limited by the institutional factors or framework conditions, such as scarce resources, political governance, limited access to finance and inadequate business development training, which ultimately inhibit their success (Atiase, Mahmood, Wang, \& Botchie, 2018; Kairiza, Kiprono, \& Magadzire, 2017; Lock \& Smith, 2015). In an effort to minimise the negative impact of institutional factors on entrepreneurship, the concept of an entrepreneurial ecosystem designed to support entrepreneurs' business-venturing process was introduced by governments, scholars, policy-makers and other stakeholders (Stam, 2015). The concept of an entrepreneurial ecosystem (Alvedalen \& Boschma, 2017; Audretsch, Cunningham, Kuratko, Lehmann, \& Menter, 2019) was based on the notion of interactions between multiple interdependent actors and factors. These included government, financial institutions, higher education, support services, talent and a culture that supports the development of a new venture (Hechavarría \& Ingram, 2019; Stam, 2015). In less industrialised countries, including Botswana, most of the 
entrepreneurial ecosystems are still in the nascent phase of development (Sheriff \& Muffatto, 2015).

Although the concept of an entrepreneurial ecosystem is gaining popularity in sub-Saharan Africa and other parts of the world (e.g. Atiase et al., 2018), there is a need to problematise ecosystem research with a gendered approach and to expose its inherent gender bias (McAdam, Harrison, \& Leitch, 2019). Entrepreneurial ecosystem research is underpinned by an assumption that all entrepreneurs have equal access to resources, without acknowledging that, most often, woman entrepreneurs are disadvantaged and questioning how such disadvantage occurs (Brush, Edelman, Manolova, \& Welter, 2019). In this regard, Hechavarría and Ingram (2019) argue that, although it is clear that an entrepreneurial ecosystem promotes entrepreneurship, there is limited research focussing on women in this role. Furthermore, there is scarce empirical evidence of how women develop their own networks within the entrepreneurial ecosystems (McAdam et al., 2019). Therefore, with a gender lens, this study answered a call to further investigate how woman entrepreneurs influence the development of entrepreneurial ecosystems in an African emerging market context, sub-Saharan Africa.

An argument raised in this study was that entrepreneurial ecosystems are still in the nascent phase of development in developing countries and not as formally organised as they are in developed countries (Adams, 2021; Sheriff \& Muffatto, 2015). According to the United Nations (2020), a developing country is characterised by medium to low standards of living, a moderate to low Human Development Index (HDI) rating and an industrial sector that has not achieved significant development. The United Nations (2020) data show that Botswana's 2019 HDI was relatively high at 0.739 , as a result of increased life expectancy at birth, expected and mean years of school attendance and gross national income per capita (United Nations, 2020). We selected Botswana because of an observation that, although the country's level of development has been impressive over the years compared with other sub-Saharan African countries (Barczikay, Biedermann, \& Szalai, 2020; United Nations, 2020), the woman entrepreneurs' ecosystem is still in a developmental phase (Sheriff \& Muffatto, 2015). This suggests that the majority of woman entrepreneurs in Botswana have to create their own ecosystem. Studying woman entrepreneurs' ecosystems in the context of Botswana, where they are not yet formalised, calls for consideration of an alternative view by focussing on how woman entrepreneurs create their own ecosystem, rather than considering such a system developed or offered by government at policy level (Spigel \& Harrison, 2018). This alternative approach was aimed at enhancing the voice of the woman entrepreneur, to derive implications for entrepreneurial ecosystem research and business practices.

As such, Stam's (2015) notion was adopted in this study that an entrepreneurial ecosystem must be studied from the level of the entrepreneurs to enable a better understanding of the context in which they operate. This view is consistent with that held by Spigel and Harrison (2018), who argue that entrepreneurial ecosystems are driven by entrepreneurs primarily around the creation of networking structures, support organisations and the task of identifying critical needs. Other actors, including governmental institutions and the private sector, play a supporting role and provide the required resources. Therefore, the research questions that this study aimed to answer were: 'How do woman entrepreneurs in a developing country context of Botswana create their own entrepreneurial ecosystems that support their business venture journey?' and 'What are some of the activities that form critical components of their entrepreneurial ecosystems?'

The articlestarts with a contextual overview of entrepreneurship in Botswana, followed by a review of existing literature, a description of the research design and a discussion of the findings. The article concludes with implications for entrepreneurs, potential applications in practice and avenues for future research.

\section{Entrepreneurship in Botswana}

For centuries, developing countries, particularly those in sub-Saharan Africa, have grown their economies by relying on their renewable and non-renewable natural resources (Edoho, 2015). Although this reliance has been beneficial in their economic development, these economies will have to put in place diversification strategies to reduce their dependence on natural resources. One such country is Botswana, which has a small population of approximately 2.5 million people (Central Intelligence Agency, 2020). Botswana is a landlocked country in the southern part of Africa (Central Intelligence Agency, 2020), largely characterised by its desert landscape and expanses of grazing fields. Since gaining independence in 1966, Botswana has grown its economy through a heavy reliance on diamonds, tourism and beef exports (Sheriff \& Muffatto, 2015).

Although diamonds have been a key contributor to Botswana's economic development (Sheriff \& Muffatto, 2015), authors warn that a decline in 'easily accessible diamond reserves in the near future' will adversely affect the country's development (Barczikay et al., 2020, p. 7). In an effort to ensure economic growth and diversification, the government of Botswana put in place an economic diversification strategy that included the development of entrepreneurship (Sekwati, 2010). This strategy resulted in the development of policies and programmes that promote entrepreneurship across various sectors, including agriculture, technology, healthcare and education (Sekwati, 2010).

Turning to entrepreneurship as a career is a growing trend amongst women in developing countries (Mastercard, 2019). Governments are putting in place structures and policies to support enterprises led by women, as they have realised the impact women have on their close communities (Kairiza et al., 2017). In Botswana, such government-endorsed organisations include the Citizen Entrepreneurship 
Development Agency (CEDA), a funding organisation; the Local Enterprise Authority (LEA), set up to support entrepreneurs from the inception of their business to its incubation; the Botswana Innovation $\mathrm{Hub}(\mathrm{BIH})$; and the Botswana Development Corporation (BDC) (Themba \& Josiah, 2015). The entrepreneurship development initiatives that were created by the government of Botswana have improved entrepreneurial activities amongst women (Mastercard, 2019). For example, Mastercard's Index of Woman Entrepreneurs demonstrates that Botswana is one of the countries with healthy business ownership rates according to gender (Mastercard, 2019). However, whilst growing numbers of women participate in entrepreneurial activities, there remains the need to address some of the key institutional and resource-based challenges facing woman entrepreneurs (Rudhumbu, Du Plessis, \& Maphosa, 2020).

\section{Institutional theory in research on women entrepreneurship}

Research on entrepreneurial ecosystems of women is often reinforced by institutional theory. Davis and North (1970) argued that the institutional environment is 'a set of fundamental political, social, and legal ground rules that govern economic and political activity' (p. 132). Scott (2005) expanded the definition of institutional theory as:

$[A]$ theory that attends to the deeper and more resilient aspects of social structure; it considers the processes by which structures, including schemas, rules, norms, and routines become established as authoritative guidelines for social behaviour. (p. 2)

Scott (2005) argues that the success of woman entrepreneurs' ecosystems is not only influenced by women's personal attributes and traits, but also by their surrounding environment - social, political and cultural institutions (Aidis \& Weeks, 2016; Coleman, Henry, Orser, Foss, \& Welter, 2019). Although there is support for woman entrepreneurs in both business practice and scholarship, there is still a gap in entrepreneurship literature regarding the institutional factors that influence business growth of ventures owned by women (Rugina, 2019).

\section{Entrepreneurial ecosystem}

Entrepreneurial ecosystems are environments in which entrepreneurs have access to resources that enable them to make use of business opportunities they have identified (Hechavarría \& Ingram, 2019; Stam, 2015). Entrepreneurial ecosystems are made up of different factors, components and actors that all contribute to the entrepreneurial prosperity in a particular geographical region (Roundy, Bradshaw, \& Brockman, 2018). According to Isenberg (2011), for entrepreneurial ecosystems to be beneficial to their recipients or actors, they should be made up of components such as a conducive culture, enabling policies, leadership, access to finance, high-quality human capital, venture-friendly markets for the sale of their products and a range of institutional and infrastructural support systems.
Sperber and Linder (2019) explain that effective entrepreneurial ecosystems may encourage other aspiring entrepreneurs to identify and utilise business opportunities, thereby increasing job creation, economic activity and reducing poverty. Therefore, there must be co-ordination of and/or interaction between the social, cultural and institutional components to support entrepreneurs in their business ventures (Maroufkhani, Wagner, \& Ismail, 2018). In Botswana, the government has introduced various mechanisms to establish the entrepreneurial ecosystem; yet, there is a lack of co-ordination between these organisations in interventions (Sheriff \& Muffatto, 2015). Most of the programmes are pioneered by the government (Pansiri \& Yalala, 2017) with minimal contribution from the private sector (Sheriff \& Muffatto, 2015). The next section provides an analysis of the components of an entrepreneurial ecosystem in the context of Botswana.

\section{Components of the entrepreneurial ecosystem in Botswana}

\section{The entrepreneur}

Spigel and Harrison (2018) argue that entrepreneurial ecosystems are built by entrepreneurs selecting the networks, mentors, funders and other players with whom they would like to interact. There is increasing focus on the concept of woman entrepreneurship in Botswana, with the aim to understand how they engage in entrepreneurial activities and become key players in the ecosystem (Mmereki, Hovorka, \& Gwebu, 2020; Rudhumbu et al., 2020). These studies have shown that, to date, women in Botswana are marginalised and lack access to finance, technical skills and markets (Rudhumbu et al., 2020). Despite these challenges, woman entrepreneurs in Botswana have achieved a noteworthy rate of business ownership of $36 \%$ of all businesses. This puts Botswana in third position of the top 10 markets of woman business owners globally (Mastercard, 2019). Rudhumbu et al. (2020) note that, despite the lack of business support in Botswana, woman entrepreneurs continue to thrive in their entrepreneurial activities. This finding suggests that woman entrepreneurs are important players in the entrepreneurial ecosystem.

\section{Cultural factors}

Walsh, Winsor and Winsor (2019) define culture as 'the attitudes, values, and norms that make up the collective mindset of the people within a specific geographic area' (p. 5). Research shows that business start-up rates amongst women are affected by cultural practices that may facilitate or inhibit entrepreneurial activities (Brush et al., 2019; Ntseane, 2004). Scholars discovered that in Botswana, there are still many negative attitudes towards an entrepreneurial culture (Josiah \& Themba, 2015). A study conducted on a sample of 76 women graduates in Botswana demonstrated that they regard jobs in the private sector as attractive career options (Rametse \& Huq, 2015). In addition, some of the traditional practices, for example, a preference for marriage over self-employment and marginalisation because of patriarchy make it difficult for women to participate in entrepreneurial activities (Kitindi, 
2006; Ntseane, 2004). However, in recent years, the Government of Botswana has committed itself to reducing the legislative and economic gap between men and women by establishing organisations that support the development of entrepreneurship in women (Rametse \& Huq, 2015).

\section{Social factors}

In most cases, entrepreneurs start their businesses through engagements with social networks that provide them with the necessary emotional support, resources and knowledge required when executing entrepreneurial activities (Neumeyer, Santos, Caetano, \& Kalbfleisch, 2019). According to Spigel (2017), 'There are four main social attributes of entrepreneurial ecosystems: the networks themselves; investment capital; mentors and dealmakers; and worker talent' (p. 53). Further, Spigel (2017) argues that family members play a significant support role in the entrepreneurial ecosystem. However, a recent study conducted on 400 women entrepreneurs in Botswana discovered that a lack of family support did not impact business performance (Rudhumbu et al., 2020). These findings suggest that despite the social challenges that women are facing even from their families or the communities, they still pursue entrepreneurial activities.

\section{Government}

Spigel and Harrison (2018) are of the view that governments should pay more attention to playing the role of an overall coordinator and supporter in entrepreneurial ecosystems. In its role of building entrepreneurial ecosystems, governments must ensure that policies and infrastructure support and promote entrepreneurship (Atiase et al., 2018). Although the government's entrepreneurship development model is robust, there is still a need to address the challenges faced by woman entrepreneurs (Josiah \& Themba, 2015; Rudhumbu et al., 2020; Sheriff \& Muffatto, 2015). The government could formulate public-private partnerships (PPPs) to encourage the participation of women in entrepreneurial projects. In Botswana PPPs are seen as a contractual agreement between organisations in the public and private sectors, whereby the private sector provides infrastructure-related services (Republic of Botswana, 2009). Existing research shows that governments use PPPs to improve entrepreneurial activities to reduce poverty (Goel \& Rishi, 2012) and promote sustainable development (Los Ríos-Carmenado, Ortuño, \& Rivera, 2016). The Government of Botswana's view is that PPPs empower small, medium and micro-enterprises (SMMEs) to enhance economic growth and employment opportunities (Republic of Botswana, 2009). Despite the significance of PPPs in fostering entrepreneurial opportunities, research in Botswana focussed mainly on PPPs in housing delivery (Kalabamu \& Lyamuya, 2017), development finance (Botlhale, 2016) and health (Ramiah \& Reich, 2005). This gap calls for entrepreneurship research to investigate PPPs as one of the significant elements of entrepreneurial ecosystems.

\section{Financial institutions}

Access to funding is arguably one of the key contributors to entrepreneurial success (Yacus, Esposito, \& Yang, 2019).
Funding provides capital for the start-up phase, as well as for the expansion and acquisition of the assets required for conducting business (Atiase et al., 2018). Entrepreneurs tend to access funding from different sources; these include not only friends and family members, but also investors and banks (Brush et al., 2019). According to Huang (2016), when entrepreneurs invest their own personal funds into their businesses, it demonstrates their commitment to and passion for the venture. Entrepreneurs in Botswana also reported that a lack of funding as one of the major challenges that affect their business activities (Pansiri \& Yalala, 2017; Rudhumbu et al., 2020). Despite the existence of government organisations, some woman entrepreneurs continue to face challenges in securing funding (Rudhumbu et al., 2020).

\section{Access to human capital and training}

Universities and other educational institutions in an entrepreneur's geographical area are usually the main source of human capital (Spigel, 2017). Pansiri and Yalala (2017) explain that Botswana's government introduced training programmes to improve the entrepreneurial and managerial skills of women in business, as woman entrepreneurs in Botswana are reported to be lacking these (Mmereki et al., 2020; Rudhumbu et al., 2020). Public-private partnerships could also be formed to promote a culture of innovation and human capital development (Acs, Stam, Audretsch, \& O'Connor, 2017). Some scholars argue that Botswana's government should consider introducing customised human capital development programmes to address the skills gap found amongst woman entrepreneurs (Rudhumbu et al., 2020).

\section{Digital entrepreneurial activities}

Sussan and Acs (2017) define a digital ecosystem as:

[A] self-organising, scalable, and sustainable system composed of heterogeneous digital entities and their interrelations, focusing on interactions among entities to increase system utility, gain benefits, and promote information sharing, as well as inner- and inter-cooperation, and system innovation. (p. 58)

Research shows that digital platforms open up opportunities for entrepreneurs to build their presence online ( $\mathrm{Li}, \mathrm{Du}, \&$ Yin, 2017). Li et al. (2017) point out that as digital innovation continues to develop it should become a part of an ecosystem for entrepreneurs, because it enables collaboration and learning. There is scant research in the context of Botswana on the prevalence of digital entrepreneurial activities, suggesting that this area requires future investigation (Duncombe \& Heeks, 2002; Mutula \& Van Brakel, 2006). One such study found that most businesses were not ready to use digital platforms (Mutula \& Van Brakel, 2006). The Government in Botswana has put forward measures to support digital transformation (Sedimo, Bwalya, \& Du Plessis, 2011), and researchers should thus investigate entrepreneurs' digital readiness.

In summary, institutional theory was considered a suitable theoretical framework for this study, which had an aim to demonstrate that woman entrepreneurs' success is not only 
affected by their personal attributes, but also their surrounding environment, including social setting, politics, culture and regulations (Aidis \& Weeks, 2016). Institutional theory had been used in similar research to explore how the different research settings influence the regulative, cultural and cognitive pillars of institutions (Singh, Sinha, Das, \& Sharma, 2019). Therefore, the presence and utilisation of the institutional environment, to a large extent, determine the success of each element of the entrepreneurial ecosystem (Rugina, 2019).

\section{Women's experiences of entrepreneurial ecosystem}

A study by McAdam et al. (2019) found that women's experience of entrepreneurial ecosystems depends on whether or not it is a women-only group. Women-only ecosystems tend to be support groups, whereas the mixed-gender groups contribute to improving the business profiles of woman entrepreneurs. Additionally, women in mixed groups have to overcome the patriarchal nature of the entrepreneurship field and learn how to play the game by imitating the practices of men (McAdam et al., 2019). Moreover, woman entrepreneurs' ability to formulate networks within the entrepreneurial ecosystem was found to be influenced by the stage of business development. Experienced woman entrepreneurs were advantaged compared with novices in building networks (Neumeyer et al., 2019).

McAdam et al. (2019) note that women-only groups prepare nascent entrepreneurs for mixed-group ecosystems where most of the actors are advanced entrepreneurs. Women were found to be negatively influenced by a perceived lack of skills and compensated by gaining support from others (Sperber \& Linder, 2019). Empirical evidence further shows that, even in a perceived supportive environment, women rely on social support from their networks (Sperber \& Linder, 2019). Although there is limited research on women's experiences in Botswana, Rudhumbu et al. (2020) found that the perceived lack of entrepreneurial skills and gender discrimination negatively influence the success of entrepreneurial ventures owned by women. Contrary to Sperber and Linder (2019), Rudhumbu et al. (2020) found the lack of support from family members as ecosystem actors did not influence the success of women-owned businesses. These discussions demonstrate that there are multiple factors that influence these women's experiences within their entrepreneurial ecosystem.

\section{Methodology}

The study followed qualitative approach and an interpretivist research design, which yielded in-depth insights and meanings from the woman entrepreneurs on how they identified the different actors and formed relationships with them (Roundy et al., 2018; Thanh \& Thanh, 2015). In addition, the design gave a 'voice to women's experiences in their own right as an under-represented and under-researched group in entrepreneurship' (Leitch, Hill, \& Harrison, 2010, p. 77). The interviewed woman entrepreneurs were able to share what is meaningful to them as they engage in entrepreneurial activities (Saunders, Lewis \& Thornhill, 2017). The inductive approach used to analyse the data was significant, as this was one of few studies on woman entrepreneurs' ecosystems in the sub-Saharan African context, and specifically in Botswana (Sheriff \& Muffatto, 2015). This research was aimed at understanding the 'how' and 'why' of the entrepreneurial ecosystems in Botswana.

\section{Data collection}

A purposive non-probability sampling method was used to select woman entrepreneurs based on their position in the business, business duration, type of business (formal sector) and a perceived history of business success (i.e. business continuity over the years and a footprint in Botswana). The sample size was 11 woman entrepreneurs based in Botswana's capital city, Gaborone (Table 1), and the unit of analysis was individual woman entrepreneurs.

Semi-structured interviews lasting $30 \mathrm{~min}$ to $60 \mathrm{~min}$ were conducted at the participants' businesses over a period of 4 weeks. Interviews were audio-recorded with prior consent having been obtained from the participants. The recordings were transcribed through a software application and verified against the audio-recordings. The entrepreneurs reviewed their transcripts and were available to answer additional questions from the researchers to clarify any inconsistencies. Verification of transcripts, member checking and clarification improved the internal validity of the findings.

\section{Data analysis}

The three-level Gioia data analytical process was used to analyse the data (Gioia, Corley, \& Hamilton, 2013), which is suitable for inductive data analysis to develop empirical concepts. First-order terms were assigned to participants' responses (Azungah, 2018). In the second level of analysis, first-order terms with similar meanings were grouped to form the second-order themes. Second-order themes that were not answering the research questions were excluded from the study. The final data structure is displayed in

TABLE 1: List of participants.

\begin{tabular}{lllc}
\hline Participant & Industry & Position in the business & $\begin{array}{c}\text { Number of } \\
\text { employees }\end{array}$ \\
\hline P1 & Insurance & Majority partner & 27 \\
P2 & $\begin{array}{l}\text { Beauty/cosmetics } \\
\text { manufacturing }\end{array}$ & Founder and owner & 10 \\
P3 & Beauty and spa treatment & Founder and owner & $10+$ \\
P4 & Media/social media analysis Founder and owner & $4+$ \\
P5 & Dentistry & Founder and owner & 4 \\
P6 & Transport and logistics & Founding partner and & $100+$ \\
P7 & Hotel and hospitality & Founder and owner & $20+$ \\
P8 & Hotel and hospitality & Founder and owner & $30+$ \\
P9 & Management consulting & Founder and owner & 10 \\
P10 & Real estate & Founder and owner & 5 \\
P11 & Shoe manufacturing and & Founder and owner & 4 \\
& retail & & \\
\hline
\end{tabular}




\begin{tabular}{|c|c|c|}
\hline 1st-order terms & 2nd-order themes & Aggregate dimensions \\
\hline $\begin{array}{l}\text { Provide funding, implement women entrepreneurship policy, } \\
\text { facilitate access to markets and provide technical and business } \\
\text { management support }\end{array}$ & $\begin{array}{l}\text { Institutional support } \\
\text { expectations }\end{array}$ & \\
\hline Limited access to markets, training challenges and inadequate funding & $\begin{array}{l}\text { Institutional support } \\
\text { challenges }\end{array}$ & \\
\hline $\begin{array}{l}\text { Passionate, joyful, hard-working, disciplined, bold, caring, able to } \\
\text { make decisions and agile }\end{array}$ & Entrepreneurial proclivity & \\
\hline Trial and error, failing business and no market for products & Entrepreneurial failure & $\begin{array}{l}\text { Entrepreneurial } \\
\text { behaviours }\end{array}$ \\
\hline $\begin{array}{l}\text { Perception that women are inadequate, weak, lack capabilities and } \\
\text { require special treatment }\end{array}$ & $\begin{array}{l}\text { Overcoming } \\
\text { marginalisation }\end{array}$ & \\
\hline Family members, husbands, fathers, mothers and siblings & Strong ties & \\
\hline $\begin{array}{l}\text { Business mentors, friends, other woman entrepreneurs, professional } \\
\text { associations and effective government officials }\end{array}$ & Weak ties & \\
\hline $\begin{array}{l}\text { Recruitment, training staff, business management, branding, } \\
\text { finances and operations }\end{array}$ & Self-taught skills & \\
\hline $\begin{array}{l}\text { Human resources, finances, operations, business management, } \\
\text { administration and strategic planning }\end{array}$ & Training institutions & \\
\hline $\begin{array}{l}\text { Learning about international processes and } \\
\text { systems, products and markets }\end{array}$ & International benchmarking & \\
\hline Family savings, parents, selling own assets and starting small & Self-funding & \\
\hline Government, banks and stokvels & External funding & \\
\hline $\begin{array}{l}\text { Supporting localisation activities, collaborating with other women } \\
\text { and choosing partners with different skills }\end{array}$ & Local partnerships & \\
\hline $\begin{array}{l}\text { Strategic partnerships, expansion across borders, developing } \\
\text { international value chains, buying equity and global mindset }\end{array}$ & International partnerships & \\
\hline $\begin{array}{l}\text { Online stores, automated processes, cross-border business model, } \\
\text { agility, disruptive business models and online platforms }\end{array}$ & Digital business model & 7. \\
\hline $\begin{array}{l}\text { Digital entrepreneurial markets and actors, including suppliers, } \\
\text { customers and partners }\end{array}$ & $\begin{array}{l}\text { Digital interactions with } \\
\text { ecosystem actors }\end{array}$ & \\
\hline
\end{tabular}

FIGURE 1: Data structure.

Figure 1, which shows how the first-order themes informed the second-order themes. Those with similar meanings were grouped into aggregate dimensions.

During the analysis, the researcher continuously crosschecked the emerging aggregate dimensions against the existing literature (Gioia et al., 2013). Categories that revealed entrepreneurs' motives for starting a business were excluded, as inclusion would have compromised the depth of the study.

\section{Findings}

The findings show that woman entrepreneurs who possess entrepreneurial behaviours are able to overcome marginalisation and embrace entrepreneurial failure, building their own ecosystems. Women who build their own entrepreneurial ecosystems have social capital ties, practise human capital development, have access to markets and funding mechanisms and engage in digital entrepreneurial activities. These ecosystem elements are surrounded by institutional conditions. The findings are presented according to the seven aggregate dimensions shown in Figure 1.

\section{Aggregate dimension 1: Institutional conditions}

Building an entrepreneurial ecosystem does not take place in a vacuum, but it is influenced by the amount of institutional support that the entrepreneur receives from the government. The participants identified the government as an important actor within the ecosystem to provide funding, implement women-friendly entrepreneurship policy, facilitate access to 
markets and provide technical and business management support.

Some entrepreneurs highlighted that the government support services were insufficient and sometimes not related to their entrepreneurial activities. There was an agreement that one of the significant challenges was poor access to funding, which the government is not able to provide to all woman entrepreneurs:

'We went and looked around, could not find anything, went to CEDA. CEDA rejected us after almost eight months. Not even any funding.' (P5, Founder and owner, Dentistry)

In some cases, when the government is not able to provide for their needs, women turn to the private financial institutions. Some woman entrepreneurs had benefitted by applying for funding from private banking institutions, but some were rejected:

'We really did not have enough, so we went to the banks. They all turned us down. They told us that we are a new establishment, we have not even been operating for six months, and we should make a U-turn. It was really frustrating.' (P6, Founding partner and owner, Transport and logistics)

Participants emphasised that the government does not seem to understand who or what entrepreneurs are and how they operate. The government should consider the new industries, which are emerging.. These findings are important, because without understanding exactly what represents the concept and the needs of an entrepreneur, government-designed ecosystems will not meet woman entrepreneurs' needs:

'I have found that the structures that are created in the country, supposedly for an ecosystem, do not understand the entrepreneur. They could not help me with anything.' (P10, Founder and owner, Real estate)

Professional associations are part of their networks. However, most of the entrepreneurs mentioned that they did not gain sufficient business management skills, but were only offered access to networks. It is therefore clear that there is a need to develop systems that are interlinked, to ensure that entrepreneurs are well supported:

'Governments would have to create a network of opportunities, or those that create networks, which is the ecosystem ... how we all work together. I have noticed that you need networks to get people working together and supporting each other to set up.' (P4, Founder and owner, Media/social media analysis)

Finally, the findings reveal that the participants approached the government rather than PPPs for funding and training. There is no evidence of significant collaborative or contractual projects that the woman entrepreneurs executed for the government.

\section{Aggregate dimension 2: Entrepreneurial behaviours}

There are specific qualities that entrepreneurs must possess to establish an entrepreneurial ecosystem, such as an entrepreneurial inclination, the ability to deal with failure and the capacity to overcome marginalisation by society. The participants viewed themselves as passionate and hardworking and noted that they cared about the development of others, especially young girls, and that they were bold enough to make difficult decisions:

'I do not let fear stop me from doing the things that I would like to do. If I am not sure, I discuss it with people around me.' (P1, Majority partner, Insurance)

The women noted that, as the entrepreneurial journey is uncertain and filled with many setbacks and disappointments, one of the important qualities required for establishing an effective ecosystem is the ability to cope with business failure. Building their own ecosystems had involved the process of trial and error by testing many business avenues, business relationships and opportunities:

'I learned the hard way. I had to close one of my other stores because it was not doing well. I focussed on one store and other strategies.' (P2, Founder and owner, Beauty/cosmetics manufacturing)

There was consensus amongst participants that woman entrepreneurs are perceived differently from their male counterparts. However, the women who participated in this study emphasised that they were able to build their own successful ecosystems because they viewed themselves as capable and did not require any special treatment or 'spoonfeeding'. They had recognised that they would have to overcome marginalisation:

'I have never put this woman thing to front, because it deters us from being who we are. I have always been in the man's world, and I have always been competent. I am on a par with them. Therefore, what is the difference? I can beat them at any game. I do not want to be treated with soft gloves because I am of a certain gender.' (P1, Majority partner, Insurance)

\section{Aggregate dimension 3: Social capital ties}

The findings show that woman entrepreneurs rely on strong as well as weak ties to support their entrepreneurial start-up and later activities. Strong ties include family members, such as parents, siblings and husbands. Most of the participants indicated that their husbands played a crucial role in the ecosystem by helping them discover their passion, acting as a source of encouragement and providing financial support:

'I have my husband as a business partner. When you say ... if there was a stumbling block somewhere, I know that he will chip in. He is very supportive in that regard.' (P8, Founder and owner, Hotel and hospitality)

However, some women had experienced resistance from their immediate families for starting business ventures. This was based on the notion that the entrepreneurial culture is still nascent in most developing countries, including Botswana. One participant stated:

'We need to accept that our families are not used to new businesses. The culture of a business they know are those that have tenders and shops. If you do not have a shop or a butchery, then how is it a business?' (P10, Founder and owner, Real estate) 
Beyond their close families, woman entrepreneurs tend to rely on distant ties who provide them with support and assist in decision-making regarding activities in which they want to engage. These ties include successful woman entrepreneurs, retired executives, business mentors, friends and knowledgeable governmental officials:

'I used my mentor to help me make difficult decisions. Sometimes you need somebody to give you the confidence to make a right decision.' (P1, Majority partner, Insurance)

It was evident that mentorship played a significant role in their entrepreneurial development. However, some related that they had not had sufficient mentoring when they launched their enterprises and were forced to learn through experience and observing other entrepreneurs. Today, they are paying it forward by mentoring others:

'... we never had any mentors to assist us. We were our own mentors, and, today, at least I am happy. I have mentored a few young Batswana [women], who are now successfully running their businesses.' (P6, Founding partner and owner, Transport and logistics)

\section{Aggregate dimension 4: Human capital development}

The second-order themes related to human capital development were self-taught skills, training institutions and international benchmarking. The participants had some form of basic business education, but it was not necessarily related to their entrepreneurial activities. Many had searched for educational programmes that would equip them with skills to manage their businesses. Some had acquired degrees such as a Master of Business Administration (MBA), which had provided them with an understanding of how the different business units function, including human resources, operations, marketing and finance:

'I got my learning through my MBA - how to start a business, how to do your market research, how to do your external assessment, how to do a competitor analysis, and how to put those things together, and I came up with a business plan.' (P10, Founder and owner, Real estate)

Some mention that the skills they possessed were self-taught. As they engaged in business activities and experimented, they learnt new sets of skills, which they were also able to pass on to their employees:

'I started to recruit and then trained my staff. I am self-taught. I started to recruit and then trained my staff to the standard that I have created for my brand.' (P3, Founder and owner, Beauty and spa treatment)

Finally, the findings showed that the woman entrepreneurs had not relied only on local training institutions, but also travelled internationally to benchmark their skills and potential ventures against leading companies and similar businesses in other countries, such as Brazil, China, Dubai, South Africa and Turkey:

'We went to Dubai. I literally lived in Dubai for three months, understanding their systems, their processes.' (P6, Founding partner and owner, Transport and logistics)

\section{Aggregate dimension 5: Access to markets and partnerships}

The participating entrepreneurs also highlighted the significance of access to local markets to distribute products. However, they emphasise that government and the private sector rarely involve local companies in their value chains:

'It is more from government and corporates to believe in local companies, because some of the challenges that I come across in business are that we do not get a lot of support from big private companies and government.' (P4, Founder and owner, Media/ social media analysis)

In dealing with these challenges, women partner with each other to strengthen their entrepreneurial ecosystem. Some women have established productive partnerships with other woman entrepreneurs, whereas some women are still struggling to establish such ties:

'I have totally been on the shoulders of a lot of women, contrary to a belief that women do not give other women business.' (P10, Founder and owner, Real estate)

The woman entrepreneurs also revealed that business opportunities were limited because of saturated local markets. They then resorted to identifying export and marketing opportunities beyond the borders of their countries. They single-handedly established international initiatives and sought business partners to achieve their objectives. They preferred to enter markets in other countries, as it is difficult to launch a business in a foreign country without having expert advice or a thorough knowledge of that country:

'We are looking to go into Zambia and Zimbabwe. It would be strategic partnerships with those people. My belief is it is really difficult to start afresh in a foreign market. My strategy would be to identify a partner there and buy an equity share.' (P1, Majority partner, Insurance)

\section{Aggregate dimension 6: Funding mechanisms}

In the early stages of starting their businesses, the entrepreneurs most often used their own money as seed capital. They also sought financial assistance from their close networks, especially parents and husbands. Some were forced to sell their properties or assets to generate the needed capital, because they did not have a financial track record with which to apply to financial institutions for funding and could not yet show any business successes:

'I literally emptied my accounts to start this company. That was a very big risk on my part. I remember my husband telling me how I have just taken the worst decision of my life, and him expressing his unhappiness towards my idea.' (P6, Founding partner and owner, Transport and logistics)

Once they had built a track record in business, most tended to approach private and governmental funding institutions for financial assistance. They adopted the strategy of first amassing a significant amount of capital on their own, so that they needed to borrow less:

'We said, "Let us just sell what is there, then we will see how much we are willing to come up with, so that, when we go to the 
bank, at least we have reduced the required amount".' Founder and owner, Hotel and hospitality)

'I got assistance from government. They gave us two million pulas [Botswana's currency]. Their limit was two million, and then our money was insufficient, because I think the project went up to two million and about 300000 [approximately US\$27 000].' (P7, Founder and owner, Hotel and hospitality)

Some of these woman entrepreneurs decided to use only their own money because they did not want to incur debt. One participant (P10) noted that the biggest thing that kills women is the fear of owing people. They minimised their potential debt by starting small - with what they have - and then re-investing their profits into their business. Some women used their local stokvels for financial support:

'You have an opportunity to grow money, no matter how little that money is. In the last year, I would get money from my stokvel, say 10000 pula [Approximately US\$900].' (P11, Founder and owner, Shoe manufacturing and retail)

\section{Aggregate dimension 7: Digital entrepreneurial activities}

The study's findings suggest that woman entrepreneurs' business landscape is changing to embrace digital platforms. They emphasised that their businesses and they as entrepreneurs have to be adaptable and agile, able to change their business models and create digital entrepreneurial ecosystems. Most of the woman entrepreneurs explained that they had started acquiring digital knowledge and skills to be able to function beyond their bricks-and-mortar locations:

'Now, with the online store, everything can actually just be on the platform. That will help us to access markets that we are not really active in. They can actually have access to our products.' (P11, Founder and owner, Shoe manufacturing and retail)

The move into the digital space suggests that woman entrepreneurs must seek entrepreneurial ecosystem actors suppliers and partners, both local and international - who are available on digital platforms and explore new markets:

'I do have a network internationally, people who have digital businesses in Africa. So, it was from that network that I was like,

"This is something that can be done in Botswana, but it is not a complex business."' (P10, Founder and owner, Real estate)

Although digital businesses are growing and entrepreneurs are upskilling themselves to exploit this business approach, participants highlighted that government should take on the critical role of providing sufficient infrastructure to support digital activities:

'Government can come in and help businesses with that, to make them aware that it is good to do business online and digital, because that is where the world is going.' (P8, Founder and owner, Hotel and hospitality)

\section{Discussion}

\section{Women entrepreneurial ecosystem}

The purpose of the study was to explore how female entrepreneurs create their own entrepreneurial ecosystem in
Botswana. The findings showed that the ecosystems created by female entrepreneurs include their social capital ties, human capital development, alternative funding mechanisms, access to markets and digital technology. These findings are consistent with those of the entrepreneurial ecosystem research conducted by Hechavarría and Ingram (2019), Stam (2015) and Sussan and Acs (2017). This study contributes to the body of knowledge in this domain through the finding that entrepreneurs actively search for, select and interact with actors who will contribute to the development of their business. This finding is important, because extant literature scarcely acknowledges how entrepreneurs select and interact with other entrepreneurial actors (Stam, 2015).

The main contribution of our study is entrepreneurial ecosystem development as seen from woman entrepreneurs' perspective. The study revealed that, to build their own ecosystem, women must already be engaged in entrepreneurial behaviours related to an entrepreneurial inclination. They have to be able to overcome prejudices and marginalisation and have to hold a positive attitude towards failure and 'pick themselves up again'.

Secondly, the participating female entrepreneurs relied on both their strong and weaker ties for resources. The strong ties are 'relationships with high emotional commitment and high frequency of contact', whilst weaker ties are characterised by 'low emotional commitment and low frequency of contact' (Martinez \& Aldrich, 2011, p. 8). Research in this field should acknowledge the diversity of such ties and how these play different roles across the different stages of business development.

Thirdly, their human capital development occurred through self-taught skills, international benchmarking and training institutions. Fourthly, because access to markets is a challenge for most entrepreneurs, the woman entrepreneurs relied on partnerships with other local businesswomen and developed international partnerships. Research in this domain does not explicitly acknowledge the importance of international partnerships, which should be emphasised as part of a robust entrepreneurial ecosystem, especially in countries with saturated local markets. Local PPP projects must also be considered in developing an entrepreneurial ecosystem.

Fifthly, a significant number of female entrepreneurs found it difficult to access funding and opted to start their businesses on a small scale, by using their personal savings and funds from stokvels. Stokvels are mutual benefit and saving societies, where a group of people contributes money to a common pool (Verhoef, 2001) for savings, burials and high-budget investments (Matuku \& Kaseke, 2014). The indigenous cultural practice of a stokvel should be acknowledged as an important dimension of the entrepreneurial ecosystem, a dimension that can support, enhance and improve entrepreneurial activities.

Finally, the participants were embracing digital entrepreneurial ecosystems by creating and refining their own business models and seeking international partners. This indicates that 


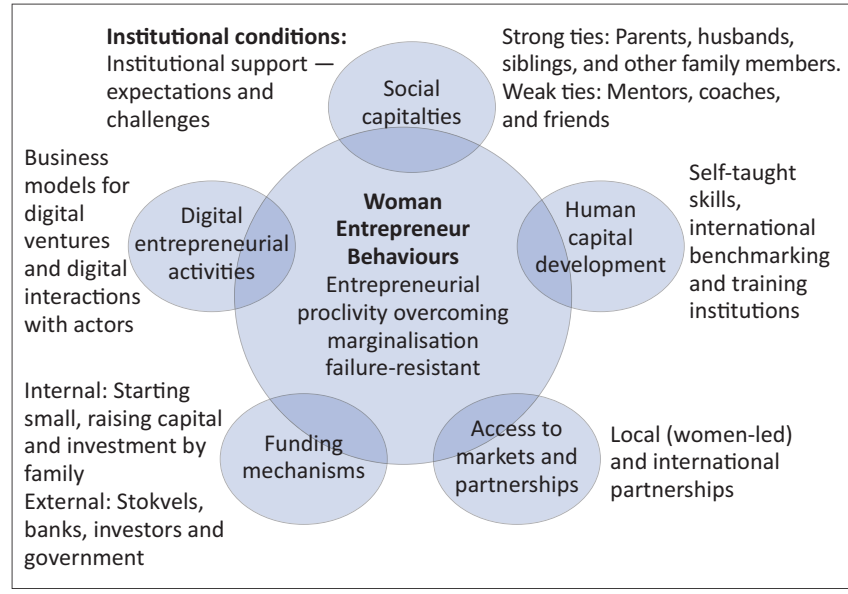

FIGURE 2: Entrepreneurial ecosystem of women in Botswana.

woman entrepreneurs are gearing up through business models for digital ventures and associated collaborations.

Figure 2 is based on the study's findings and shows the entrepreneurial ecosystem created by female entrepreneurs in Botswana, together with the surrounding institutional conditions.

Each element of the women entrepreneurial ecosystem is explained in the following sections.

\section{Institutional conditions: The role of government and private sector}

Participants explained that entrepreneurial ecosystems in Botswana were underdeveloped, by stating that the government as the key player was not able to sufficiently meet the needs of entrepreneurs. Some of the needs include access to funding, programmes specifically designed to address their business needs and access to markets. Although there are programmes in place in Botswana, their implementation is ineffective. This confirms the finding of Spigel and Harrison (2018) that governments do not fully understand entrepreneurship and consequently have difficulty developing suitable support programmes. Atiase et al. (2018) explain that, for the government to become a valuable contributor to entrepreneurial ecosystems, there should be sponsored programmes and institutions that are effective in executing their mandates and serving their customers. Botswana's government should identify the different female entrepreneurial requirements and clearly define their role in the entrepreneurial ecosystems. In this regard, Spigel (2017) points out that most government programmes are geared towards supporting informal entrepreneurs, those who do not have any access to resources or networks, rather than high-potential candidates for the formal sector. Government should collaborate with non-governmental organisations (NGOs) and other actors in both the public and private sector. There is evidence that some of the leading entrepreneurial ecosystems are successful because of interaction between multiple actors, where the government provides risk reduction whilst institutions of higher education develop human capital and skills, with banks providing the financing (Adams, 2021).

Furthermore, the reviewed literature showed that the government of Botswana uses PPP projects to empower SMMEs to create employment (Republic of Botswana, 2009). However, the participants did not explicitly mention PPPs as a factor in their entrepreneurial ecosystems. Botlhale (2016) argues that there had previously been a slow uptake of PPPs in Botswana, as evidenced by few current PPP projects, but that this is improving. This presents an opportunity for future research to explore the role of PPPs in female entrepreneurial ecosystems.

\section{Entrepreneurial behaviours}

The findings of this study show that woman entrepreneurs acknowledge that the creation of a successful entrepreneurial ecosystem requires an entrepreneurial inclination, combined with the ability to overcome marginalisation and a positive attitude towards viewing failure as a stepping stone and knowing how to proceed. Moreover, the entrepreneurial behaviours such as not giving up in the face of failure and overcoming marginalisation are also significant characteristics. These findings are aligned with those of McAdam et al. (2019), who argue that women in mixed entrepreneurial groups overcome marginalisation by imitating the practices of men.

\section{Social capital ties}

The participants benefitted mostly from their social networks when building their entrepreneurial ecosystems. Firstly, they relied on their close ties - family members, and then their distant networks, consisting of mentors, friends and established business owners. Neumeyer et al. (2019) argue that social capital greatly contributes to entrepreneurs' ability to start and grow their businesses by giving them the necessary emotional support and sharing their resources, knowledge and experience. When analysing the findings, it is evident that woman entrepreneurs with high-growth businesses have access to diverse ties that contribute to their entrepreneurial success at different points in their journey (Martinez \& Aldrich, 2011). Some participants had had access to mentors later in their entrepreneurial journey, and some relied on their own entrepreneurial learning through trial and error. These findings are consistent with those of Mamabolo, Kerrin and Kele (2017), who argue that, in the early entrepreneurial stages, many entrepreneurs have limited access to mentorship. In some cases, female entrepreneurs have access to only one mentor, who then serves different purposes as the business develops (Martinez \& Aldrich, 2011). Research on entrepreneurial ecosystems has generally focussed on support from multiple actors, without explaining their exact roles. Women should also develop international ties with knowledge of their local market when expanding into foreign markets. Support programmes for entrepreneurs should include providing mentorship, and women should be encouraged to strengthen their social capital. 


\section{Human capital development and access to market}

The entrepreneurial ecosystem should include education facilities, where some entrepreneurs learn the skills they need to succeed in businesses (Maroufkhani et al., 2018). However, the findings showed that most participants had to rely on self-taught skills, private training institutions and their personally funded international benchmarking. Mamabolo et al. (2017) argue that entrepreneurs without access to formalised business education are forced to rely on trial and error, failure and experimentation, lowering their chances of success (Deakins, Bensemann, \& Battisti, 2016; McKay \& Chung, 2005). Some participants undertook tertiary education, such as an MBA degree, to acquire the specialised knowledge and skills required to manage their business. As recommended by Spigel (2017), entrepreneurial ecosystems should provide access to skilled human capital through networks and institutions of higher education, who should develop entrepreneurship-specific programmes.

The study's findings showed that woman entrepreneurs were involved in the entrepreneurial skill development of the girl child in Botswana. This finding is important as it demonstrates the need to mentor the girl child on entrepreneurial activities. Anyebe (2015) argued that promoting the girl child entrepreneurial education will enhance the production of women who identify and exploit entrepreneurial opportunities. Therefore, children should be exposed to entrepreneurship at an early age through tailor-made entrepreneurial programmes and experiential learning activities (Jufri \& Wirawan, 2018; Paço \& Palinhas, 2011).

\section{Funding mechanisms}

Aligned with the findings of Martinez and Aldrich (2011), the current study found that woman entrepreneurs often use their personal funds as seed capital and sometimes seek financial assistance from family and friends, banks and the government. In alignment with the finding of Berndt (2016), the present study found that the women also relied on stokvels, especially in developing countries with scarce formal resources. Only once their businesses were established with a demonstrable track record were they able to approach private financial institutions. Programmes to support the development of woman entrepreneurs should therefore include enabling them to access the necessary funding for seed capital and running costs, coupled with teaching them skills to manage their businesses' finances.

\section{Digital entrepreneurship activities}

Finally, some participants used digital platforms to learn new skills, collaborating with ecosystem actors to trade their products within and outside of Botswana (see Song, 2019). Other participants commented that they had found their suppliers on digital platforms, and that they also learnt how to create products through online resources. Sussan and Acs (2017) explain that entrepreneurs are also using the digital platforms to access markets that are not located in their geographical areas. The Internet is enabling woman entrepreneurs in Botswana to become agile and adapt their business models. The introduction of agile practices helped these entrepreneurs use online platforms to grow and improve their businesses, both within and outside Botswana. Other woman entrepreneurs should thus be encouraged to embrace digital platforms as part of their entrepreneurial ecosystems.

\section{Conclusion}

This research was focussed on gaining an understanding of how successful female entrepreneurs had built their entrepreneurial ecosystem in the context of Botswana, through their own perceptions. These woman entrepreneurs selected and interacted with various ecosystem actors who provided support at the different stages of their business development. They created their ecosystems by identifying critical components of an ecosystem - social capital ties, human capital development, access to markets, partnerships and digital actors - that were important at different stages in the development of their businesses. Budding woman entrepreneurs in similar contexts could learn from these women's journeys and apply the wisdom these women had gained, often the hard way, through trial and error and costly experience.

\section{Implications for woman entrepreneurs and woman leaders in Africa}

This study yielded five points of advice for aspirant woman entrepreneurs. Firstly, they should use their social networks to connect with mentors and successful entrepreneurs and keep building this social capital in all facets of their business, to gain information, knowledge, practical know-how, ideas for innovation and resources. Secondly, they should collaborate amongst themselves and with external sources of funding to raise the funds to establish their business. Thirdly, entrepreneurs should identify what education and training they require to be successful. Then, they should actively seek appropriate mentorship and formal education and join forums where others with experience could be of assistance. Fourthly, entrepreneurs should keep abreast of and keep in step with the unstoppable globalisation of markets and trends. They should avail themselves of opportunities, remain informed regarding trends to position their businesses in the market and stay ahead of threats. Lastly, woman entrepreneurs should actively and continuously explore opportunities to form strategic partnerships with government and PPPs, and, themselves, contribute momentum to a circle of development by mentoring novice woman entrepreneurs.

In closing, woman leaders and successful woman entrepreneurs in Africa are in a position to connect woman entrepreneurs, government and private institutions, thereby paving the way for woman entrepreneurs to flourish. One practical option is to foster entrepreneurship in women through dedicated PPP projects. Woman leaders can then act as intermediaries to fill the gaps in woman entrepreneurs' ecosystems in partnership with society, private companies and government institutions. Such initiatives should be comprehensive and integrated, and implemented at regional, national and country level. 


\section{Implications for government and private organisations}

The findings showed that there is a mismatch between government's entrepreneurial initiatives and the expectations of woman entrepreneurs. Government should thus focus on identifying the needs of woman entrepreneurs to ensure the alignment necessary to enable these women to flourish in their business ventures. To grow Botswana's economy, the government should place more emphasis on creating support initiatives for formal firms with high growth potential rather than informal businesses. The impact would be amplified if these initiatives, including training programmes, are tailored to the needs of different types of enterprises. The government, in joint efforts with PPPs, should also encourage and assist in creating collaboration to support emerging digital ventures, to avoid enterprises becoming outdated and redundant because of globalisation. Finally, government should encourage investors, angel investors and venture capitalists to participate in entrepreneurial ecosystems as financiers and mentors to woman entrepreneurs.

\section{Limitations and avenues for future research}

The sample of this study was limited, as the focus was on woman entrepreneurs who had succeeded in their ventures. Therefore, the findings do not provide a wider view of different entrepreneurs' experiences, and thus the generalisability of the findings is limited. Future research could include women who did not succeed in their business ventures, as this would yield insights into the failures of entrepreneurial ecosystems. The sample consisted only of woman entrepreneurs in Gaborone, and future research could include other African countries to obtain a multicountry focus and findings that may be generalisable to similar contexts. The current study found that different ecosystem actors are critical at different stages of the development of an entrepreneurial venture. Future research could follow a longitudinal design to explore this dynamism. There is also a need to evaluate the policies that are meant to support the entrepreneurial activities of women in Botswana, which should include how government and PPPs could build trusting relationships with woman entrepreneurs through collaboration and the promotion of local business ventures.

\section{Acknowledgements \\ Competing interests}

The authors declare that they have no financial or personal relationships that may have inappropriately influenced them in writing this article.

\section{Authors' contributions}

R.L. conducted the research under the supervision of A.M. A.M. was responsible to restructure the study's conceptual argument and write the final manuscript.

\section{Ethical considerations}

This article followed all ethical standards for research, with ethical clearance obtained from the Gordon Institute of Business Science, University of Pretoria.

\section{Funding information}

This research received no specific grant from any funding agency in the public, commercial or not-for-profit sectors.

\section{Data availability}

The authors confirm that the data supporting the findings of this study are available within the article.

\section{Disclaimer}

The views and opinions expressed in this article are those of the author and do not necessarily reflect the official policy or position of any affiliated agency of the author.

\section{References}

Acs, Z.J., Stam, E., Audretsch, D.B., \& O'Connor, A. (2017). The lineages of the entrepreneurial ecosystem approach. Small Business Economics, 49(1), 1-10. https://doi.org/10.1007/s11187-017-9864-8

Adams, S.B. (2021). From orchards to chips: Silicon Valley's evolving entrepreneurial ecosystem. Entrepreneurship and Regional Development, 33(1-2), 15-35. https:// doi.org/10.1080/08985626.2020.1734259

Adom, K., \& Asare-Yeboa, I.T. (2016). An evaluation of human capital theory and female entrepreneurship in sub-Saharan Africa. International Journal of Gender and Entrepreneurship, 8(4), 1756-6266. https://doi.org/10.1108/IJGE-12-2015-0048

Aidis, R., \& Weeks, J. (2016). Mapping the gendered ecosystem. International Journa of Gender and Entrepreneurship, 8(4), 1756-6266. https://doi.org/10.1108/IJGE12-2015-0044

Alvedalen, J., \& Boschma, R. (2017). A critical review of entrepreneurial ecosystems research: Towards a future research agenda. European Planning Studies, 25(6), 887-903. https://doi.org/10.1080/09654313.2017.1299694

Anyebe, A.A. (2015). Girl-child education and entrepreneurship in Nigeria. Journal of Social and Administrative Sciences, 2(4), 197-204.

Atiase, V.Y., Mahmood, S., Wang, Y., \& Botchie, D. (2018). Developing entrepreneurship in Africa: Investigating critical resource challenges. Journal of Small Business and Enterprise Development, 25(4), 644-666. https://doi.org/10.1108/ JSBED-03-2017-0084

Audretsch, D.B., Cunningham, J.A., Kuratko, D.F., Lehmann, E.E., \& Menter, M. (2019). Entrepreneurial ecosystems: Economic, technological, and societal impacts. The Journal of Technology Transfer, 44(2), 313-325. https://doi.org/10.1007/s10961018-9690-4

Azungah, T. (2018). Qualitative research: Deductive and inductive approaches to data analysis. Qualitative Research Journal, 18(4), 383-400. https://doi.org/10.1108/ QRJ-D-18-00035

Barczikay, T., Biedermann, Z., \& Szalai, L. (2020). An investigation of a partial Dutch disease in Botswana. Resources Policy, 67, 101665. https://doi.org/10.1016/j. resourpol.2020.101665

Berndt, A. (2016). Crowdfunding in the African context: A new way to fund ventures. In L. Achtenhagen \& E. Brundin (Eds.), Entrepreneurship and SME management across Africa (pp. 31-49). Singapore: Springer.

Botlhale, E.K. (2016). Financing development through public private partnerships (PPPs) in Botswana. Africa's Public Service Delivery \& Performance Review, 4(1), 26-49. https://doi.org/10.4102/apsdpr.v4i1.105

Brush, C., Edelman, L.F., Manolova, T., \& Welter, F. (2019). A gendered look at entrepreneurship ecosystems. Small Business Economics, 53(2), 393-408. https:// doi.org/10.1007/s11187-018-9992-9

Central Intelligence Agency (CIA). (2020). World fact book Botswana. Retrieved March 17, 2021 from https://www.cia.gov/the-worldfactbook/countries/botswana/

Coleman, S., Henry, C., Orser, B., Foss, L., \& Welter, F. (2019). Policy support for women entrepreneurs' access to financial capital: Evidence from Canada, Germany, Ireland, Norway, and the United States. Journal of Small Business Management, 57(Suppl 2), 296-322. https://doi.org/10.1111/jsbm.12473

Davis, L., \& North, D. (1970). Institutional change and American economic growth: A first step towards a theory of institutional innovation. The Journal of Economic History, 30(1), 131-149. https://doi.org/10.1017/S0022050700078633

Deakins, D., Bensemann, J., \& Battisti, M. (2016). Entrepreneurial skill and regulation. International Journal of Entrepreneurial Behavior and Research, 22(2), 234-259. https://doi.org/10.1108/IJEBR-12-2014-0240 
Duncombe, R., \& Heeks, R. (2002). Enterprise across the digital divide: Information systems and rural microenterprise in Botswana. Journal of International Development, 14(1), 61-74. https://doi.org/10.1002/jid.869

Edoho, F.M. (2015). Guest editorial: Entrepreneurship paradigm and economic renaissance in Africa. African Journal of Economic and Management Studies, 6(1) 2-16. https://doi.org/10.1108/AJEMS-11-2014-0086

Goel, G., \& Rishi, M. (2012). Promoting entrepreneurship to alleviate poverty in India: An overview of government schemes, private-sector programs, and initiatives in the citizens' sector. Thunderbird International Business Review, 54(1), 45-57. https://doi.org/10.1002/tie.21437

Gioia, D.A., Corley, K.G., \& Hamilton, A.L. (2013). Seeking qualitative rigor in inductive research: Notes on the Gioia methodology. Organizational Research Methods, 16(1), 15-31. https://doi.org/10.1177/1094428112452151

Hechavarría, D.M., \& Ingram, A.E. (2019). Entrepreneurial ecosystem conditions and gendered national-level entrepreneurial activity: A 14-year panel study of GEM. Small Business Economics, 53(2), 431-458. https://doi.org/10.1007/s11187-0189994-7

Huang, H.C. (2016). Entrepreneurial resources and speed of entrepreneurial success in an emerging market: The moderating effect of entrepreneurship. International Entrepreneurship and Management Journal, 12(1), 1-26. https://doi.org/10.1007/ s11365-014-0321-8

Isenberg, D. (2011). The entrepreneurship ecosystem strategy as a new paradigm for economic policy: Principles for Cultivating Entrepreneurship. Institute of International and European Affairs (pp. 1-13). Dublin, Ireland, 12 May 2011.

Josiah, J., \& Themba, G. (2015). Entrepreneurship development in Botswana: Lessons for other developing countries. Botswana Journal of Business, 8(1), 11-35.

Jufri, M., \& Wirawan, H. (2018). Internalizing the spirit of entrepreneurship in early childhood education through traditional games. Education and Training, 60(7/8), 767-780. https://doi.org/10.1108/ET-11-2016-0176

Kairiza, T., Kiprono, P., \& Magadzire, V. (2017). Gender differences in financial inclusion amongst entrepreneurs in Zimbabwe. Small Business Economics, 48(1), 259-272. https://doi.org/10.1007/s11187-016-9773-2

Kalabamu, F.T., \& Lyamuya, P.K. (2017). An assessment of public-private partnerships in land servicing and housing delivery: The case study of Gaborone, Botswana. Current Urban Studies, 5(4), 502-519. https://doi. org/10.4236/cus.2017.54029

Kitindi, E.G. (2006). Barriers to growth of urban-based small scale female entrepreneurship in Botswana. Botswana Institute of Administration and Commerce Journal, 3(2), 1-24.

Leitch, C.M., Hill, F.M., \& Harrison, R.T. (2010). The philosophy and practice of interpretivist research in entrepreneurship: Quality, validation, and trust.
Organizational Research Methods, 13(1), 67-84. https://doi.org/10.1177/ Organizational Resear
1094428109339839

Li, W., Du, W., \& Yin, J. (2017). Digital entrepreneurship ecosystem as a new form of organizing: The case of Zhongguancun. Frontiers of Business Research in China, 11(1), 69-100. https://doi.org/10.1186/s11782-017-0004-8

Lock, R., \& Smith, H.L. (2015). The impact of female entrepreneurship on economic growth in Kenya. International Journal of Gender and Entrepreneurship, 8(1) 90-96. https://doi.org/10.1108/IJGE-11-2015-0040

Los Ríos-Carmenado, D., Ortuño, M., \& Rivera, M. (2016). Private-public partnership as a tool to promote entrepreneurship for sustainable development: WWP Torrearte experience. Sustainability, 8(3), 199. https://doi.org/10.3390/ surrearte

Mamabolo, M.A., Kerrin, M., \& Kele, T. (2017). Human capital investments as sources of skills: An analysis at different entrepreneurship phases. The Southern African Journal of Entrepreneurship and Small Business Management, 9(1), 1-12. https:// Journal of Entrepreneurship and Small
doi.org/10.4102/sajesbm.v9i1.114

Maroufkhani, P., Wagner, R., \& Ismail, W.K.W. (2018). Entrepreneurial ecosystems: A systematic review. Journal of Enterprising Communities: People and Places in the Global Economy, 12(4), 545-564. https://doi.org/10.1108/JEC-03-2017-0025

Martinez, M.A., \& Aldrich, H.E. (2011). Networking strategies for entrepreneurs: Balancing cohesion and diversity. International Journal of Entrepreneurial Behaviorand Research, 17(1),7-38. https://doi.org/10.1108/13552551111107499

Mastercard. (2019). Mastercard index of women entrepreneurs (MIWE) 2019. Mastercard. Retrieved September 18, 2019 from https://www.mastercard.com/ news/media/yxfpewni/mastercard-index-of-womenentrepreneurs-2019.pdf

Matuku, S., \& Kaseke, E. (2014). The role of stokvels in improving people's lives: The case in Orange Farm, Johannesburg, South Africa. Social Work, 50(4), 504-515. https://doi.org/10.15270/50-4-388

McAdam, M., Harrison, R.T., \& Leitch, C.M. (2019). Stories from the field: Women's networking as gender capital in entrepreneurial ecosystems. Small Business Economics, 53(2), 459-474. https://doi.org/10.1007/s11187-018-9995-6

McKay, R.B., \& Chung, E. (2005). Benchmarking for entrepreneurial survival. Benchmarking: An International Journal, 12(3), 207-218. https://doi. org/10.1108/14635770510600339

Mmereki, D., Hovorka, A., \& Gwebu, T. (2020). A gender analysis of microentrepreneurship in developing-transition countries: Insights from Botswana. International Journal of Entrepreneurship and Small Business, 39(3), 395-429. https://doi.org/10.1504/IJESB.2020.104986

Mutula, S.M., \& Van Brakel, P. (2006). E-readiness of SMEs in the ICT sector in Botswana with respect to information access. The Electronic Library, 24(3), 402-417. https://doi.org/10.1108/02640470610671240
Neumeyer, X., Santos, S.C., Caetano, A., \& Kalbfleisch, P. (2019). Entrepreneurship ecosystems and women entrepreneurs: A social capital and network approach. Small Business Economics, 53(2), 475-489. https://doi.org/10.1007/s11187-018Small Busil

Ntseane, P. (2004). Being a female entrepreneur in Botswana: Cultures, values, strategies for success. Gender and Development, 12(2), 37-43. https://doi.org/10 strategies for success. Gender and
$.1080 / 13552070412331332180$

Paço, A.D., \& Palinhas, M.J. (2011). Teaching entrepreneurship to children: A case study. Journal of Vocational Education and Training, 63(4), 593-608. https://doi. org/10.1080/13636820.2011.609317

Pansiri, J., \& Yalala, A.T. (2017). The evolution of entrepreneurship and small-to-medium business development in Botswana. Botswana Journal of Business, 10(1), 53-79.

Rametse, N., \& Huq, A. (2015). Social influences on entrepreneurial aspirations of higher education students: Empirical evidence from the University of Botswana women students. Small Enterprise Research, 22(1), 1-16. https://doi.org/10.1080/ 13215906.2015.1018381

Ramiah, I., \& Reich, M.R. (2005). Public-private partnerships and antiretroviral drugs for HIV/AIDS: lessons from Botswana. Health Affairs, 24(2), 545-551.

Republic of Botswana. (2009). Public-private partnerships policy (2009). Harare: Government Printing and Publishing Services.

Roundy, P.T., Bradshaw, M., \& Brockman, B.K. (2018). The emergence of entrepreneurial ecosystems: A complex adaptive systems approach. Journal of Business Research, 86, 1-10. https://doi.org/10.1016/j.jbusres.2018.01.032

Rudhumbu, N., Du Plessis, E., \& Maphosa, C. (2020). Challenges and opportunities for women entrepreneurs in Botswana: Revisiting the role of entrepreneurship education. Journal of International Education in Business, 13(2), 183-201. https:// doi.org/10.1108/JIEB-12-2019-0058

Rugina, S. (2019). Female entrepreneurship in the Baltics: Formal and informal context. International Journal of Gender and Entrepreneurship, 11(1), 1756-6266. https://doi.org/10.1108/IJGE-05-2018-0055

Saunders, M., Lewis, P., \& Thornhill, A. (2016). Research methods for business students (Vol. 7). London: Pearson Education.

Scott, W.R. (2005). Institutional theory: Contributing to a theoretical research program. Great Minds in Management: The Process of Theory Development, 37(2), 460-484.

Sedimo, N.C., Bwalya, K.J., \& Du Plessis, T. (2011). Conquering the digital divide: Botswana and South Korea digital divide status and interventions. South African Journal of
Information Management, 13(1), 1-10. https://doi.org/10.4102/sajim.v13i1.471

Sekwati, L. (2010). Botswana: A note on economic diversification. Botswana Journal of Economics, 7(11), 79-85. https://doi.org/10.4314/boje.v7i11.64205

Sheriff, M., \& Muffatto, M. (2015). The present state of entrepreneurship ecosystems in selected countries in Africa. African Journal of Economic and Management Studies, 6(1), 17-54. https://doi.org/10.1108/AJEMS-10-2012-0064

Singh, S., Sinha, S., Das, V.M., \& Sharma, A. (2019). A framework for linking entrepreneurial ecosystem with institutional factors: A modified total interpretive structural modelling approach. Journal for Global Business Advancement, 12(3), 382-404. https://doi.org/10.1504/JGBA.2020.10033252

Song, A.K. (2019). The digital entrepreneurial ecosystem - A critique and reconfiguration. Small Business Economics, 53(3), 569-590. https://doi. org/10.1007/s11187-019-00232-y

Sperber, S., \& Linder, C. (2019). Gender-specifics in start-up strategies and the role of the entrepreneurial ecosystem. Small Business Economics, 53(2), 533-546. https://doi.org/10.1007/s11187-018-9999-2

Spigel, B. (2017). The relational organization of entrepreneurial ecosystems. Entrepreneurship: Theory and Practice, 41(1), 49-72. https://doi.org/10.1111/ Entrepreneurs
etap.12167

Spigel, B., \& Harrison, R. (2018). Toward a process theory of entrepreneurial ecosystems. Strategic Entrepreneurship Journal, 12(1), 151-168. https://doi. org/10.1002/sej.1268

Stam, E. (2015). Entrepreneurial ecosystems and regional policy: A sympathetic critique. European Planning Studies, 23(9), 1759-1769. https://doi.org/10.1080/0 9654313.2015.1061484

Sussan, F., \& Acs, Z.J. (2017). The digital entrepreneurial ecosystem. Small Business Economics, 49(1), 55-73. https://doi.org/10.1007/s11187-017-9867-5

Thanh, N.C., \& Thanh, T.T. (2015). The interconnection between interpretivist paradigm and qualitative methods in education. American Journal of Educational Science, 1(2), 24-27.

Themba, G., \& Josiah, J. (2015). Entrepreneurship development in Botswana: Lessons for other developing countries. Botswana Journal of Business, 8(1), 11-35. https://doi.org/10.1590/S0102-44501999000200014

United Nations. (2020). World economic situation and prospects 2020. New York, NY: United Nations Publications.

Verhoef, G. (2001). Informal financial service institutions for survival: African women and stokvels in urban South Africa, 1930-1998. Journal of Economic and Financial Sciences, 25(1), 49-62. https://doi.org/10.1093/es/2.2.259

Walsh, J., Winsor, B., \& Winsor, B. (2019). Socio-cultural barriers to developing a regional entrepreneurial ecosystem. Journal of Enterprising Communities: People and Places in the Global Economy, 13(3), 263-282. https://doi.org/10.1108/JEC11-2018-0088

Yacus, A.M., Esposito, S.E., \& Yang, Y. (2019). The influence of funding approaches, growth expectations, and industry gender distribution on high-growth women entrepreneurs. Journal of Small Business Management, 57(1), 59-80. https://doi. org/10.1111/jsbm.12491 